KRAUSZ Bernadett

PhD-hallgató, PTE ÁJK

Bírósági fogalmazó, Nagykanizsai Járásbíróság
DOI: 10.15170/DIKE.2020.04.02.05

\title{
Magyar magánjogászok a német jog hatásáról és a jogfosztásról (1920-1944)
}

\section{Hungarian Private Lawyers about the Influence of German Law and the Restriction of Rights (1920-1944)}

The study aims to discover the Hungarian relations to the Academy for German Law between 1920-1944 and the influence of German law to Hungarian Civil law. It also analyses the reaction of Hungarian jurists to the right restrictions and deprivations of the Horthy era concerning Civil law, whether they welcomed or criticized them and more importantly, if they spoke about them at all publicly. I examined the legal papers that were published in the subject period, namely the Journal of Law, Civil Law and Hungarian Legal Review in order to seek answers.

Keywords: private law, Horthy era, Academy for German Law, restriction of rights, deprivation of rights, German influence

„Persze, hogy mely idók normálisakés melyek nem azok, ez felfogás és sokban - éréékenység dolga. Vajon ma normálisak-e? Vagyunk egynéhányan, akik arra habozás nélk.ül nemmel felelünk. A bivatalos felfogás azonban az, hogy igen. Fiat applicatio."

\section{Bevezető gondolatok és módszertan}

A Német Jogakadémia (Akademie für Deutches Recht) Külügyi Osztályát 1933 és 1934 fordulóján állították fel, feladatuk a jogösszehasonlítás és a külföldi jogászokkal való szakmai kapcsolat kiépítése volt. A német és magyar jogösszehasonlítást egy munkaközösség keretében végezték, ${ }^{2}$ a két állam több szakmai találkozó alkalmával ismertette a saját jogrendszerének múködését. A tanulmányban azt vizsgálom, hogy a Hortby-korszakban (1920-1944) a Német Jogakadémia milyen hatással volt a magyar magánjogtudomány fejlődésére, tekintettel arra, hogy magas beosztású magyar jogászok is szerepeltek a levelező tagjai között, így a közigazgatási jogász, Magyary Zoltán (1888-1945) professzor, Mikeč Ödön (1894-1965), aki 1938. március 9. és 1938. november 15. között igazságügyminiszterként szolgált, Osvald István (1867-1944), aki 1934 és 1937 között a Kúria elnöke volt, az egyházjogász bíró, Stolpa József (1887-1958), Töreky Géza (1937-1944), aki 1937 és 1944 között volt a Kúria elnöke, Vladár Gábor (1881-1972), aki az igazságügyi tárcát vezette 1944.

\footnotetext{
${ }^{1}$ MeSZLÉNY, Nyári tépelődések 105-106.

${ }^{2}$ Herger, Az igazságosság és a jogtalanság határai 9.
} 
augusztus 29. és 1944. október 16. között, valamint Radocsay Lášló (1878-1968), aki 1939. november 9. és 1944. március 22. között volt igazságügyi miniszter. ${ }^{3}$

Indokolt továbbá annak a felkutatása is, hogy a korszak jogfosztó, jogkorlátozó intézkedéseirôl a korabeli magyar magánjogászok milyen módon vélekedtek, illetve, hogy mennyiben adtak hangot a véleményüknek. Ennek feltárása érdekében átnéztem a Hortbykorszakban megjelent szakfolyóiratokat, így a Jogtudományi Közlöny 1920 és 1934 közöttii magánjogi tárgyú cikkeit, valamint a Polgári Jog (1925-1938) és a Magyar Jogi Szemle (1920-1944) kiadványait. A tanulmány második felében ezen folyóiratok írásaiban keresem a választ a kérdésre.

Előre bocsátandó, hogy a Magyar Jogi Szemlében főleg büntetőjogi és közjogi témájú írások találhatók, ezekhez képest elenyésző mennyiségű a magánjogi témájú közlemény, amelyeknek az áttekintése után azt tapasztaltam, hogy a magánjogi jogviszonyokat hátrányosan befolyásoló rendelkezésekre nem reflektáltak a szerzők. A Jogtudományi Közlönyben hasonló tendencia figyelhetô meg, Meszlény Artur néhány cikkén kívül nem jelent meg más olyan mú, amely releváns lenne a téma szempontjából; a Polgári Jog című folyóirat ugyanakkor bővelkedett ezekben. A fentiekre tekintettel a Jogtudományi Közlönyben és a Polgári Jogban közvetített publikációkat mutatom be külön fejezetben.

Tekintettel arra, hogy a tanulmány elsősorban az egyes magánjogászoknak a jogfosztásról és jogkorlátozásról való véleményét kívánja bemutatni a Horthy-korszakban, a nyilatkozataikat nem időrendben, hanem folyóiratonként és személyenként rendszerezve tárgyalom. Azon esetekben, amikor nem kerül kiemelésre a német hatás, a jogkorlátozó rendelkezésekre való reflektálást mutatom be.

\section{A Német Jogakadémia és kapcsolatai a magyar magánjogászokkal}

Németországban 1933-ban kötelezővé tették minden jogász számára, hogy belépjen a Német Nemzetszocialista Jogászok Szövetségébe (BNSDJ), amely az ország egyetlen jogászokat tömörítő szervezete lett, eltörölve minden korábbi jogászszövetséget. ${ }^{5}$ Ezután Hans Frank - későbbi német birodalmi igazságügyi miniszter - megalapította a nemzetszocialista ideológiájú Német Jogakadémiát. $^{6}$

A Német Jogakadémia és a magyar jogászok közötti kapcsolatokról, így az igazságügyminisztériumok képviselőinek egymásnál tett látogatásairól a sajtó is beszámolt. Ugyanazt a szöveget közölték több sajtóorgánumban, propagandaszerűen dicsőítve a németek által hirdetett eszméket és a két állam közötti baráti viszonyt, illetve a jogászok bemutatták egymásnak a saját jogrendszerüket.

Az egyik ilyen alkalmon, 1938. június 18-án, midőn a berlini városházán tartott teljes üléssel véget ért a Német Jogakadémia ötödik ülésszaka, Mikecæ tartott előadást. ${ }^{7}$ Hallgatóságként jelen

\footnotetext{
${ }^{3}$ Herger, Az igazságosság és a jogtalanság határai 9.

4 A Jogtudományi Közlöny 1866-ban indult útjára, a Tanácsköztársaság idején nem jelent meg és az 1920. évi újraindulása után is súlyos gondokkal küszködött, míg végül 1934-ben a lapot kiadó Franklin Társulat megszüntette. A lap 1946-ban indult újra, Szladits Károllyal a szerkesztőbizottság élén.

${ }^{5}$ UDVAros, A háborús bűnök nem évülnek el 683.

${ }^{6}$ A birodalmi igazságügyminiszter pályafutása és munkássága a német jog újjáalakításában 7.

${ }^{7}$ Mikecz Ödön nagysikerű előadása Berlinben a magyar alkotmány és jogalkotás fejlődéséről 7.
} 
voltak a német kormány és diplomáciai testület tagjai, illetve Németország „,csaknem valamennyi kiviáló jogász̨", magyar oldalról pedig Sžtójay Döme, az akkori berlini magyar követ is. ${ }^{8}$ Az ülésen Frank köszöntőjében hangsúlyozta a német-magyar barátságot és „különös elégtételként” tekintett arra a tényre, hogy a magyar igazságügyminiszter látogatása Magyarország kormányzójának, Hortby Miklósnak a 70. születésnapjára esik. Mikecz az előadásában beszélt a magyar alkotmány és közigazgatás legújabb fejlődéséről, a büntetőjogról, illetve arról, hogy „Magyarorsqágon nincs összefoglaló polgári törvénykönyv, csak a magánjog egyes szakaszai nyertek törvényes szabályozást” és „a legtöbb rendelkezést a szokásjog tartalmazza, amely a biróságok itélógyakorlatában jut kifejezésre”. Részletesen beszélt az 1928. évi magánjogi törvénykönyv javaslatáról és arról, hogy az Igazságügyminisztérium elkészítette a teljes német fordítását. Előadása befejezéseként elmondta, hogy érdeklődéssel hallgatta a Frank által felvázolt munkaprogramot, amely szerint a Német Jogakadémia célja, hogy az egész német jogrendszert a nemzeti szocializmusban megvalósított új szemléletnek megfelelően újjáalakítja és biztosította a hallgatóságot, hogy Magyarország állandóan figyelemmel kísérte a múködésüket és a jövőben is így fog tenni. ${ }^{9}$ Mikecz után Frank birodalmi miniszter előadásában a bemutatta a Német Jogakadémia ötéves múködését, a nemzetszocializmus egész jogi és világnézeti felfogását, valamint jogalkotó tevékenységét. Elmondta, hogy „örvendetes dolog, hogy azok az alapelvek, amelyeknek alapján a magyar törvényhozás az utóbbi években fejlödött, nagy mértékben azonosak azokekal az. alapelvek.kel, amelyek a nemzetszocialista birodalmi kormányt törvényhozói tevékenységében irányítják.” Utalt ugyanakkor arra, hogy „semmi sem áll távolabb a nemzetszocializmustól, mint ą, hogy politikája alkotórészének tekintse a szellemi kincseinek kivitelét”. Éppen ezért örvendetes számukra, „,hogy Mikecz. igåságügyminiszter úr elóadásából megismerhették a magyar szellemiség magabiztosságát." ${ }^{10}$ Ezen a napon Hitler birodalmi kancellár a német jogakadémia levelező tagjává nevezte ki Mikecz. igazságügyminisztert. ${ }^{11}$

Ezen nyári látogatás viszonzásaképpen Frank is hazánkba látogatott 1938. október 20-án, és másnap a Pázmány Péter Tudományegyetem aulájában mutatta be a Harmadik Birodalom jogalkotását. ${ }^{12} \mathrm{Az}$ előadáson jelen volt többek között Mikecz igazságügyminiszter, Töreky, a Kúria elnöke, Stolpa államtitkár, Osvald professzor, akik mind a Német Jogakadémia levelező tagjai voltak, valamint a koronaügyész Finkey Ferenc is. Frank ismertette a német jogrend „megújhodásának” vezető gondolatait, és ismét bemutatta a Német Jogakadémia munkásságát. Akként nyilatkozott, hogy a reformjaik Európa újabb jogtörténetének legjelentősebb eseményei közé fognak tartozni és mutatni fogják a német világnézet hatalmas formáló erejét, amely közéletük minden terén megnyilvánul. ${ }^{13}$ A Magyar Jogi Szemle beszámolója szerint az előadó figyelmet rendkívül lekötően, a mai német szónokoktól megszokott lendülettel elmondott, élvezetes előadás után általános volt a vélemény, hogy az előadás nem annyira jogi, mint inkább jogpolitikai keretek között mozgott. ${ }^{14}$ Előadásában újfent elmondta, hogy a „nemzeti szocialista eszuményt nem akarják más népekere rákénysžeriteni, s a nemzeti

\footnotetext{
${ }^{8}$ Magyar Távirati Iroda, 1938. június 18. 18 óra 5 perc. Mikecz igazságügyminiszter előadása, II. folytatás.

${ }^{9}$ Magyar Távirati Iroda, 1938. június 18.17 óra 20 perc. Mikecz igazságügyminiszter előadása.

10 Mikecz Ödön igazságügyminiszter előadást tartott Berlinben a magyar alkotmányjogunk és büntetőjogunk fejlődéséről 4.

${ }^{11}$ Mikecz Ödön igazságügyminiszter a Német Jogakadémia levelező tagja 12.

${ }^{12}$ Frank birodalmi miniszter Budapestre utazása előtt nyilatkozik a Budapesti Hírlapnak. 7.

${ }_{13}^{13}$ VÉRTESI, Frank dr. nyilatkozata budapesti útjáról 7.

${ }^{14}$ Dr. Hans Frank német birodalmi miniszter budapesti előadása 416-418.
} 
s₹ocializmus nem exportcikek, hanem a német államalkotó génius legsajátabb megnyilatkozása". ${ }^{15}$ Bemutatta továbbá a német népi jog megújításának fö vezérelveit, amelyet a „német nép állagértéknek nevez, ežek a faj, föld, munka, birodalom és becsület.” Az első vezérelvhez azok a jogszabályok tartoznak, amelyek a faj erős megtartását és javítását, erôsödését célozzák, ilyen az egészséges házasságok előmozdításáról szóló törvény. ${ }^{16}$

Frank birodalmi miniszer előadásaiban többször is azt hangsúlyozta, hogy a nemzeti szocialista eszmény nem exportcikk, ugyanakkor az 1941. évi XV. törvénycikk, amely a házassági törvény módosítását tartalmazta, az úgynevezett „fajvédelmi törvény” indokolása szerint hasonló elveken alapul.

A zsidók közéleti és gazdasági térfoglalásáról szóló 1939. évi IV. törvény, vagyis a II. zsidótörvény javaslatára Hungarus álnéven reflektált valaki akként, hogy a törvényjavaslat gyakorlatilag faji alapon tárgyalja a zsidókérdést, majd bemutatta az elvi alapokat, amelyek szerint a zsidó vallású emberek külön fajhoz tartoznak, betegesek, neurotikus személyek és helytelenítette, hogy a törvényjavaslat nem tiltja a keresztények és zsidók közötti vegyes házasságot, ami álláspontja szerint a magyar nép és annak egészsége védelme érdekében álló lenne. ${ }^{17}$ Végül Hungarus „kivánsága” teljesült és a „fajvédelmi törvényt” 1941. június 11. napján benyújtották a parlamentnek. ${ }^{18} \mathrm{Az}$ akkori igazságügyminiszter, Radocsay által jegyzett indokolás szerint a törvény Magyarország népességének minőségi és mennyiségi javítását kívánja előmozdítani. Ezen célok érdekében 1. kötelezővé kívánja tenni a házasságkötés előtt a házasulók orvosi vizsgálatát, 2. házasodási kölcsönt kíván biztosítani az arra szoruló egészséges házasulóknak, 3. bizonyos kóros állapotokra tekintettel továbbfejleszti a házasság megtámadására és felbontására vonatkozó rendelkezéseket, valamint 4. házasságkötési tilalmat tervez a nemkívánatos vérkeveredés meggátlására. ${ }^{19}$ A „fajvédelmi törvény”-ben tehát, amely tisztán magánjogi rendelkezéseket tartalmaz, megfigyelhető a német hatás a magyar magánjogra.

Radocsay 1941. szeptember 7. napján Berlinbe utazott a német Igazságügyi Minisztérium vezetésével megbízott Schlegerberger igazságügyi államtitkár meghívására. Az utazás során a német jogi élet vezetőivel való kapcsolatépítés mellett jogi intézményeket tekintett meg. E körben meglátogatta az Akademie für Deutches Recht-et (Német Jogakadémia), mely az ő szavaival élve „kiváló müködése során már eddig is sokban járult hozzá a magyar-német jogászi kapcsolatok kimélyitéséhez”. Beszédében megköszönte, hogy alkalmat nyújtanak neki arra, hogy megismerhesse a német igazságügy mintaszerû működését, amely hasznos tapasztalatokkal gazdagítja, és amelyeket otthon is felhasználhat. Biztosította az államtitkárt, hogy hazájának minden jogásza a legőszintébb rokonszenvet tanúsítja iránta és a német igazságügyi munkatársak iránt. ${ }^{20} \mathrm{Az}$ utazás céljai között szerepelt a német-magyar kapcsolat elmélyítése és a német igazságügyi intézmények megismerése mellett a német-magyar nemzetközi szerződésekkel kapcsolatos tárgyalások lebonyolítása. ${ }^{21}$

\footnotetext{
${ }^{15}$ Frank Hans német birodalmi miniszter előadása a magyar jogászok előtt. 6 .

16 Jogi alapokon nyugvó békékre 6 .

${ }^{17}$ Hungarus, A zsidók közéleti és gazdasági térfoglalásáról 2-3.

18 LUGOSI, „Sztálin főhercege” 527-576.

${ }^{19}$ LUGOSI, „Sztálin föhercege” 527-576.

${ }^{20}$ Radocsay igazságügyminiszter Berlinbe utazott - Meglátogatja a német bíróságokat és igazságügyi intézményket. 2.

${ }^{21}$ Magyarország felismerte az új Európában reá váró feladatokat és törvényesen megteremti a szükséges feltételeket Ünnepélyesen fogadták Berlinben a magyar igazságügyminisztert 3.; Németországi utam eredménye a legvérmesebb eredményeimet is felülmúlta - mondotta a Németországból hazaérkező Radocsay igazságügyminiszter 3.
} 
Találkozott továbbá Frankkeal és vele a jog területén adódó tudományos együttműködés kiépítésére vonatkozóan részletes megbeszélését folytattak. ${ }^{22}$

\section{Magyar magánjogászok véleménye a német hatásról és a jogkorlátozó rendelkezésekről}

A tanulmány kizárólag a magánjog körének vizsgálatára szorítkozik, ebből a szempontból a harmadik zsidótörvénynek, az ún. „fajvédelmi törvénynek” van a legnagyobb jelentősége. A kutatás során arra jutottam, hogy a jogi szakfolyóiratok ennek az ismertetésétól elzárkóztak. Két tanulmányt találtam a törvénnyel kapcsolatban, mindkettőnek a szerzője Szentmiklósi István, aki 1938-ban, az első cikk megjelenésekor királyi ítélótáblai tanácsjegyzőként, majd 1942-ben, a második cikk publikálásakor már pestvidéki királyi törvényszéki bíróként dolgozott és fejtette ki a támogató véleményét a házasságkötést megelőző orvosi vizsgálattal szemben. Egyebekben a Meszlény elnökölésével szerkesztett Polgári Jog című folyóirat tartalmazott számos olyan tanulmányt, amelyben a szerzők aggályukat fejezték ki a közjognak a magánjogba való túlzott beavatkozása ellen. Ezen kívül a magánjogászok nagyrészt nem szólaltak fel a zsidótörvények mellett vagy ellen, kivéve Márkus Dę̧ő̄ tanítványát, Meszlényt, aki kritizálta a korabeli jogfosztó és jogkorlátozó rendelkezéseket a Jogtudományi Közlöny hasábjain is.

Attól függetlenül azonban, hogy nem közölték a véleményüket explicit módon, a kutatás során találtam információt arra vonatkozóan, hogy miként vélekedtek a magánjogászok a korszak eseményeiről.

Marton Géza professzornak a Debreceni Egyetemen tartott előadásán 1932. november 14. napján egy kutya került a tanterembe, játszottak vele a diákok, amikor megjelent a professzor és megkérdezte, hogy került az állat a terembe, mely felszólításra senki nem jelentkezett. A Debreczeni Ujság szerint ${ }^{23}$ a professzor ekkor elhagyta a termet, a Magyar Hírlap szerint viszont a keresztény hallgatók azt kiáltották, hogy „a zsidók tették, takarodjanak kil’”Ezután név szerint is megvádolták a zsidó hallgatókat azzal, hogy behozták a kutyát és fenyegető magatartást tanúsítottak. Erre a zsidók elhagyták a termet. Két nappal később egy hallgató, B. Lász̧ló az óra alatt felállt és közölte, hogy a gyanúsítottakkal és tettesekkel nem hajlandók előadást hallgatni, erre $H$. Béla megkérdezte, hogy kire gondol, és felsorolta őket név szerint. $H$. kikérte a zsidók nevében a gyanúsítgatást, erre $D$. Barnabás felállt és közölte, hogy „amíg a ssidóktól a rajtunke ért sérelemért elégtételt nem kapunk, nem türjük. meg öket az elöadáson”. Marton professzor úr ezután a vitát bezárta és iparkodott meggyőzni a hallgatókat, hogy egy ember esetleges hibájáért nem lehet felelőssé tenni azt az egész közösséget, amelybe tartozik. ${ }^{24}$

Szladits Károly az általa szerkesztett Magyar magánjog címú hat kötetes múben (1939-1942), a személyi jogi részben, melynek egyúttal szerzője is volt, a jogképesség tekintetében egy mondatban érintette csupán a jogegyenlőség elvének sérelmét, amikor megnevezte a szerzőképesség korlátait, közöttük a vallási hovatartozást is. ${ }^{25}$ A korszakban közölt írásairól megállapítható, hogy nem írt a zsidótörvényekről és azok hatásairól.

\footnotetext{
22 Radocsay hétfőn este visszautazott Németországból Budapestre 7.

${ }^{23}$ A debreceni egyetem jogi fakultásán zsidó hallgatók megzavarták az előadásokat 3.

${ }^{24}$ Hogyan került egy kóbor kutya Marton Géza professzor tantermébe? 3.

${ }^{25}$ HerGER, Az igazságosság és a jogtalanság határai 9.
} 
Almási Antal 1923-ban, illetve 1924-ben publikálta Berlinben a magyar magánjogról szóló kétkötetes összefoglaló mưvét német nyelven. ${ }^{26}$ Az első kötet előszavában úgy fogalmazott, hogy ténynek tekinthetô a magyar magánjog fejlődésében megnyilvánuló erőteljes német hatás, a germán elemek léte, melyek azonban hasonultak a magyar joghoz az évszázadok folyamán. Példaként említette a kereskedelmi, váltó és csődtörvényt, amely „erösen német befolyás alatt készüllt, és a jó német mintának többé-kevésbé rossz utánz̧ása lett”. Ugyanakkor, az íratlan magyar magánjog „öseredeti”, nemzeti jellegú. Almási hangsúlyozta, hogy a német hatás a magyar magánjogban nem a törvények és a kódexek átvételével történt, hanem az általános jogi gondolatok jelentek meg itthon is, majd ezeket átalakították a szokásjogban a nemzeti jellegnek megfelelően. ${ }^{27}$ Mindezt azonban Almási még messze nem a korszak jogkorlátozó normáiról írta, hanem az épp ekkor kodifikáció alatt álló magánjogunk állapotáról.

\section{A Jogtudományi Közlöny cikkei}

A Jogtudományi Közlöny a Horthy-korszak első felében jelent csak meg, 1934-ig, majd a második világháború után indult újra útjára. A folyóiratban nem jelentek meg a jogfosztásokat és jogkorlátozásokat érintő cikkek, csupán Hungarus álnéven egy, amely üdvözölte a házassági törvény módosítására vonatkozó javaslatot. Ezzel szemben Mesz̨lény tudományosan megalapozott kritikát fogalmazott meg az állam azon intézkedéseivel szemben, amelyek szerinte túlságosan belenyúlnak a magánjogi jogviszonyokba, jogkorlátozást valósítanak meg, veszélyeztetve ezzel a jogbiztonságot. 1922 márciusában azt írta, hogy végre diadalmasan elismerésre találtak a személyiségi jogok, azonban a háborús és az azt követő törvényhozás kikezdte ezeknek az érvényesülését. Szerinte az utókor úgy fogja jellemezni ezt a korszakot, mint „, a kereseti alkalmak kisajátítása és a zoknak a végrehajtó hatalom rendelkezésre adásának kora”. A közhatalom - álláspontja szerint - túlságosan belenyúl a magánszférába, ezt látja a numerus clausus rendelkezésekben (1920. XXX. tc.) és az új ipartörvényben. Megjegyzi azonban, hogy „aそ, hogy ę tendencia milyen politikai célokat szolgált, s hogy e célokat helyeseljüke vagy nem, kivül esik a viæ̧sgálódásaink körén”. ${ }^{28}$ A „Jog eldurvulása” című írásában bírálta a törvényeket, amelyek az állami vagyon gyarapítására szolgálnak, szerinte nem az árdrágítást akadályozzák meg a szabályok, hanem inkább az árdrágítás monopóliuma megszerzésének harcáról szólnak. Kifejtette, hogy nem érzi a jogbiztonságot, valamint szerinte a törvények indokolásai elfedik a törvények valódi célját, így például „az a törvény, amely az állampolgárok. bizonyos - és nem a legtehetségtelenebb - részét a föiskolai oktatásból kirekeszuti, szavaiban ąt az intenciót birdeti, hogy a föiskolai oktatás alaposságát és eredményességét óhajtja bið̨tosítani. ${ }^{29}$ Hangot adott a földbirtokreformmal kapcsolatos aggályainak, szerinte ezzel burkolt jogkorlátozás figyelhető meg. ${ }^{30}$ Egy másik cikkében pedig rávilágít arra, hogy minden korok bölcsei és vallása azt mondják, hogy „nincs oly ember vagy embercsoport, akinek, joga volna

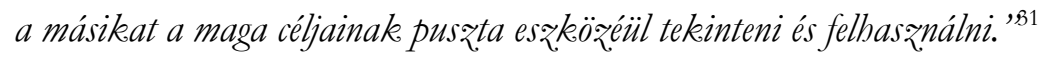

\footnotetext{
26 Szemle 159.

${ }^{27}$ ALMÁsI, A magyar magánjog jellemzése 163-164.

28 MESZLÉNY, Újabb törvényhozásunk és a magánjog 34.

${ }^{29}$ MESZLÉnY, A jog eldurvulása 69-70.

${ }^{30}$ MESZLÉNY, Földbirtokreform és magánjog 162-163., 7., 190-191.

${ }^{31}$ MESZLÉNY, Morál és jog 41.
} 


\section{A Polgári Jog cikkei}

A Beck Salamon által toborzott „Civiljogászok Vitatársasága” üléseinek népszerűségére tekintettel Mesqlény főszerkesztésével indult el a Polgári Jog címú folyóirat 1925-ben, amelynek beköszöntőjében Mes₹lény megfogalmazta a lap célját, ami nem más, mint „,közrremunkálni a romok eltakaritásán, az egymást megértés müvén, a jog visszavezetésén abba a kiegyenlitett, egyoldalúságot és elfogultságot magától messze elháritó, az emberi szenvedélyek és elöitéletek gö̋leörén túllátó magaslatra, amelyen valamikor volt." Ismereteket kívántak nyújtani, „nem riadva vissza a tárgyilagos és decens hangú bírálattól, nem pályázva kegyekre és elönyökre senkitól, kerülve a személyeskedést és a provokációt, de kérlelhetetlenül a zigazságra függesztett tekintettel."

Kiemelte, hogy a Természet törvényeinek nem vethetünk gátat, az ember ennek nem ura, valamennyiünket szabadnak, egyenlőnek és gyarlónak teremtettek. Arra intett, hogy ne gondoljuk azt, „hogy a másik már gonosz és értéktelen csak azért, mert nem egészen olyan, mint amilyennek te - képzeled magad” és ne álljuk el „a másik elöl a levegöt, a napot, mert holnap ölehet az erösebb és ö tasquit téged a mélységbe.” A háború folytán húsz millió ember pusztult el, ezzel semmivel sem lett könnyebb a lét a megmaradtak számára, mert minden dolgozó ember többletmunkát teljesít, amely együtt alkotja a társadalom nagy tartalékalapját. „Embert pusz̨titani tehát: öngyilkosság, akár nemzetközi, akár államon belüli küzdelemben történjék.”. Azt kívánta, hogy a jog „legyen az Igazság büsqke tartásúpapnöje”, „a biztos védelmet nyüjtó pajzs, amely készségesen befogad mindenkit, aki az, eröszak elöl menekül” és „ne jogtiprás squrtos és szolgálatkész pesztonkája”, ,a törvény ne legyen az eröszak végrehajtásának formája”. ${ }^{32}$

Almási a polgári törvénykönyv megalkotásáról akként vélekedett 1925-ben, a Polgári Jog című folyóirat első számában, hogy a korabeli helyzet nem alkalmas arra, hogy magánjogi kódex lépjen hatályba. A megalkotás során a fő kérdés szerinte, hogy vajon „a báború elótti szabályokat foglalja-e irásba és ezzel már eleve is tudatosan helyezkedjék szembe az élettel, avagy talán a mai állapotot állandósitsa?” A törvénykönyv létrehozását először is azért nem látta indokoltnak, mert a személyiségi jog alapjai kérdésessé váltak és szerinte „egyes törvényeink a személyiség legföbb meghatározási jogát: az önmeghatározást egyes esetekben ma már nem az egyén puszta létéhez, hanem annak. bizonyos az államnál

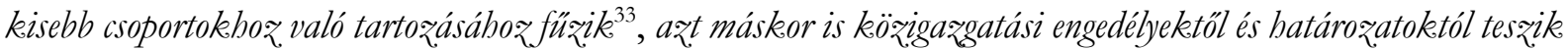
függópể, más szavakkal, hogy a személyiségi jog legfontosabb ágai magánjogi értelemben vett és mindenkit egyformán

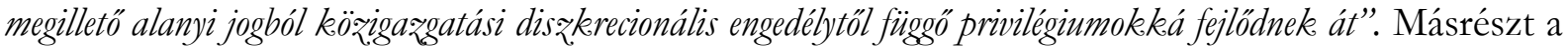
dologi jogban az ingó fogalma megváltozott, az ingatlan feletti tulajdonjog közigazgatási jellegű korlátozása (kényszerbérlet), a földbirtokreform korlátozásai által elveszett a tulajdon háború előtti tartalma. Harmadrészt a kötelmi jogot álláspontja szerint nem lehet egy gazdaságilag instabil helyzetben időtállóan szabályozni. Összességében nem tudott elképzelni sem olyan törvénykönyvet, ami a „háború elötti módon sz̨abályozza a személyiségi jogot, a tulajdonjogot és a bitelezési

\footnotetext{
32 MESZLÉNY, Beköszöntő 1-4.



34 „1920. XXV. t.cike. 3. J-a, közigazgatási engedély: az 1922. XII. t.-cike számos esete, megyei gazdasági albizottság: 1920.

XXXVI. t.-cike. 25. S, az ebben a vonatkozásban szintén közigazgatási batóságnak veendö. Földbirtokrendezón Bíróság (1920.

XXXV I. t.-cik.k. 25. S.), a Földmivelésügyi Miniszter (ugyanott 20. S.) stb. döntései, amelyek végeredményben mind afelett is határo znak, kinek van megengedve, hogy tudományos, kereskedelmi vagy ipari és mezógazdasági pályán müködhessék, kinek nem?”
} 
forgalmi szerzódéseket, sem olyat, amely ezekeról hallgat, vagy pedig a korabeli chaotikus állapotukban akarná és föleg tudná törvénybe iktatni". ${ }^{35}$

Meszlény a „Jogpolitika” címû mûvében kifejtette, hogy a gyengébb fél védelme érdekében meghozott közjogi rendelkezések annyira belenyúltak a magánjogi viszonyok szabályozásába, hogy a „sok állami gondoskodás közepette” elveszett a magyar legnagyobb kincse, a szabadsága. Szerinte az az ideális, hogyha a ,jogalkotó nem szabályoz többet, mint amennyi elkerülhetetlenül szülkséges”. ${ }^{36}$

Kifejezte az aggodalmát a tekintetben is, hogy az „1912: LXIII. t.-c. 16. $\int$-a bizonyos korlátok

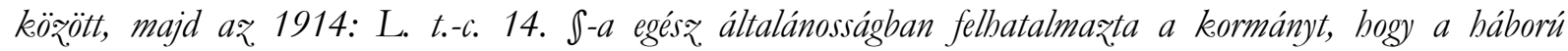
követkęztében szülkségessé vált szabályokat a magánjog terén is rendelettel állapitsa meg s az 1920: VI. t.-c. 1. I. 2. bekezdése szerint, amely a kivételes hatalmat meghosszabbitotta, a hadviselés érdeke alatt az ország belsö rendjének és közbiżtonságának, valamint külsö politikájának érdekeit is érteni kell.” Álláspontja szerint a Kúria anélkül alkalmazott rendeleteket, hogy megvizsgálta volna a felhatalmazás jogosságát a háborús helyzet elmúlta után. A magánjogi élethelyzetek rendeletekkel való szabályozásának mindenképpen a „kivételességét és mintegy végszülkségszerüséget kell követkęetesen sæẹm elött tartani”. ${ }^{37}$

Schiffer Eugen nyugalmazott német birodalmi igazságügyminiszter és helyettes kancellár Magyar Jogászegyletben tartott előadása után Mesথlény nyílt levelet fogalmazott meg felé, amelyben reflektált arra, hogy milyen párhuzamokat és különbségeket fedezett fel a háború hatásaiban a két államban. Ezek közül az egyik párhuzam az eltolódás a jogban a közjog javára és a magánjog hátrányára, ami okán az egyén önrendelkezési joga és mozgásszabadsága sérül. Azonban, amíg Németországban ez a gazdaságilag gyengébb fél védelmének érdekében történik, addig hazánkban „az általános, közérdekünek proklamált célok érdekében. Ezek a nemzet gazdasági fennmaradása és a fennálló társadalmi rend megvédése és megszilárdítása érdekében sұü̈kségesnek tartott” célok. A korlátozások által sérült a tulajdonhoz való jog, mivel a földbirtokreform lényegében revizionálja a háború óta szerzett földtulajdont a tekintetben, hogy mennyiben kell korlátozni a szerzést, hogy földtulajdonhoz juthassanak azok, akiket erre „méltónakés alkalmasnak” találnak; emellett a pályaválasztás szabadságát számos rendelkezés korlátozza, azzal „, a céllal, hogy a keresöpályákat és kereseti lehetöségeket ama társadalmi rétegek számára biztositsák és tartsák fenn, amelyeket erre bivatottaknak és alkalmasoknak tekintenek." Előadása szerint azokon a területeken, amelyeket a német reform gócpontjaként jelölt meg a helyettes kancellár, a magyaroknál alig észlelhető változás, így „az ingó vagyonra vonatkozó magánjogi szabályok alig változtak meg, a lakásbérlettel kapcsolatos korlátozó rendelkezések leépités alatt vannak, a kartellïgy szabályozása még a tervezgetés stádiumában van, s a termeló és fogyasztó, a munkaadó és munkavállaló közötti jogviszonyok rendezése terén szintén aránylag kevés változás történt.” Míg Németországban a család uralkodó fogalma mellett a házastársak személyes jogai háttérbe szorultak és a házasságon kívül született gyermekek családjogi helyzettel nem bírtak, addig hazánkban ez kevésbé égető probléma, ugyanis a jogi helyzet teljesen más. Álláspontja szerint a magyar jog a férji hatalmat a szó germán értelmében nem ismeri, férj és nő a házasságban régtől fogva elvileg egyenrangú félként áll egymással szemben, bár leszögezi, hogy konkrét statisztika nem áll rendelkezésére arról, hogy a családokban általában a férfi vagy a nô az úr. A házasságon kívüli gyermek tartásának intézményét a bírói gyakorlat kialakította és a nőnek a szülés körül felmerülő sürgős szükségletei fedezésének

\footnotetext{
35 ALMÁsI, A polgári törvénykönyv 8-13.

${ }^{36}$ MESZLÉNY, Jogpolitika. 193-196.

${ }^{37}$ MesZLÉNY, Uj jogszabálytan 334-341.
} 
kérdésérôl egy háborús rendelet ${ }^{38}$ gondoskodik, amely hatályban maradt. A családjog területe Meszlény szerint nem váltott ki általánosabb reformkívánalmakat. Míg a német jogban a „római jog uralmának hatásaként és maradványaként a jog túltechnikázottsága” jellemző, addig Magyarországon a korábbi kódexek (például a kereskedelmi törvény, büntetőtörvény, csőd- és végrehajtási törvény) a „jogalkotó fokmérójén nézve primitivek” és csak a rendkívül szabad jogalkalmazással alkalmazhatók, viszont ezáltal a bírói jogfejlesztés jellemzi ezeket a területeket. Az újabb törvények jogtechnikailag magas fokon állnak, így például a tisztességtelen versenyrôl, a szerzői jogról, a vámjogról szóló törvények, a polgári törvénykönyv javaslatának ún. bizottsági szövege, de kifejezi, hogy a „magánjogi törvénykönyv legújabb javaslatával szemben már bizonyos aggályokat ébresz̨t bennem az, hogy a birói gyakorlatból átvett új rendelkezéseknek nem mindig sikerült a birói döntés esetszerüsége alól magukat teljesen emancipálni és a konkrét eset nyersanyagából az általános jogelvet szabatosan kivésni." Kihívásnak tartja az új jogszabályok tömegességét, de ennél is súlyosabbnak, hogy „az elökészités nem folyik azzal a nyilvánossággal, mint azelött s gyakran meglepetészszerüen lépnek életbe hatalmas kódexek. nébány nap alatt, úgy, hogy még futólagos megtanulásuk is ki van zárva." Pozitívumként tekint arra 1929 januárjában, hogy a „háborús kivételes hatalom megszünte óta rendeletek sokasága megcsappant és a törvények tartalmilag jók”. A bíróságokkal kapcsolatban leszögezte, hogy hazánkban nem kellett azzal megküzdeniük, hogy magát azt az államhatalmat érezzék illegitimnek, amelynek nevében múködnek. A bíróságnak ,nem feladata, hogy az itélkeezésében a sürün felburjánzó és nagyrész̨t rövid életre szánt szélsö társadalmi áramlatokat támogassa vagy elnyomja, hanem az ö feladata csak egy: eskïjéhez, hiven, kedvezés és kedvkeresés nélküll, félelem és gyülölet nélkül, egyedül és kizárólag igazságot szolgáltatni.” Örömmel nyugtázta, hogy a magyar bírók elenyésző kivételtől eltekintve ehhez az utóbbi ideálhoz tartják magukat, így vissza fogják hódítani a bíróságok régi nimbuszát. ${ }^{39}$

Alföldy Ede, nyugalmazott ítélőtáblai tanácselnök, ügyvéd 1927-ben a „A törvényhozó hatalom korlátai” címú cikkében arra intett, hogy a korabeli „keïlönféle diktatúrák divatja idején nem árt arról gondolkozni, hogy miképpen védekezzünk az önkények annyiféle lehetösége ellen”, álláspontja szerint a bírói jogalkalmazás körének a megfelelő kiépítése elég hatékonyan ellensúlyozhatja ezeket. ${ }^{40}$

Ifj. Nagy Dezső̋ 1934-ben kifejezte aggodalmát a rendeleti államigazgatással kapcsolatban. 1922-ben némi javulás állott be, mivel az 1922. évi XVII. törvénycikk 6. \$-a kimondta, hogy a szükségtelenné vált rendeletek azonnal hatályon kívül helyezendők, a még továbbra is fenntartandók tekintetében pedig a kormány törvényjavaslatokat tartozik a nemzetgyúlés elé terjeszteni. Ezután ismét érvényesült az írott törvény elsőbbsége és felsőbbsége, az „1931-ben kirobbant pénzügyi kríris azonban nemcsak gazdasági életünket rárkódtatta meg alapjaiban, hanem az. alkotmányosság elvén is újból hatalmas rést ütött. A₹ 1931: XXVI. t.-c. 2. $\int$-a a gazdasági és hitelélet rendjének megóvása cimén eddig soha nem ismert széleskörü felhatalmazást adott a minisżériumnak. A kormány e cél érdekében rendelettel nemcsak magánjogi és eljárási, hanem egyéb olyan rendelkezéseket is tehet, melyek. alkotmányunk értelmében a törvényhozás hatáskörébe tartoznak." Ezzel megduzzadt a rendeletek száma és álláspontja szerint 1933-ban „a Rendeletek Tára fontosabb jogszabálygyújtemény, mint az Országos Törvénytár." ${ }^{* 1}$

\footnotetext{
${ }^{38} \mathrm{Az}$ eltartásta jogosult családtagok és a házasságon kívül született gyermekek fokozottabb magánjogi védelméről szóló 3982/1916. M. E. számú rendelet.

${ }^{39}$ MESZLÉNY, Az igazságügy reformjához 1-7.

${ }^{40}$ ALFÖLDI, A törvényhozó hatalom korlátai 85-87.

${ }^{41}$ IFJ. NAGY, Törvény vagy rendelet? $11-13$.
} 
Beck ugyanebben az évben szintén a gazdasági válság hatásában észlelte azt, hogy a jog alapvető elvei meginognak. A válság jogszabályai közül „egyik-másik sz̨erencsésen hozzásimul az egyetemes jogrend szabályaiboz, de sok rendelkezés a jogi alapelvekekel kerül szembe”." ${ }^{2}$

Vladár a Nemzeti Klubban, 1938. évi február 23. napján tartott előadást a „Jog elhajlása az élettől” címmel, amelyben a pozitív jognak az élettől való eltávolodásának eseteit mutatta be. Kitért arra, hogy a jog az életviszonyokat hivatott rendezni, „,e nem állhat útjában az életnek, nem fordíthatja meg åt, legfeljebb medret épithet neki.” Elörevetítette, hogy „, amennyiben a pozitiv jog elhajlik az élettöl, az. nevetség, közöny és gyülölet tárgya lesz:” Ennek két következménye lehet a desuetudo vagy forradalom. Vladár szerint a magyar nemzet azért őrizte meg jogát a római joggal és a kánonjoggal szemben, mivel „az élet szüleségleteiböl fakadt, a gyakorlatban, az élet kövein csiszolódott, az élet joga s, legalább is fö vonásaiban, a magyar élet joga volt".43

Szentmiklósi királyi ítélőtáblai tanácsjegyző a családvédelmi programot, a házasságkötést megelőző kötelező orvosi vizsgálatot (amely a házassági törvény kiegészítéséről és módosításáról szóló 1941. évi XV. törvénycikkel lépett hatályba, ez volt az ún. „fajvédelmi törvény”) mint „,nem kis jelentôségú reformot” üdvözölte. A reform - mely szerint az orvosi vélemény kötelező, a házasuló fél döntési jogát képezi, hogy házasságot köt-e, illetve az orvosi vizsgálat elmulasztása esetén büntetés jár neki, de a házasság érvényes marad - álláspontja szerint nem elégséges. Szerinte meg kell akadályozni, hogy azok, akiktől csak örökletesen beteg utód származhat, és akinek egészségi állapota a másik házastárs egészségét is veszélyezteti, házasságot köthessenek, mivel a „,salád és a családon kereszutül a nemzet egészségét tisztán kell tartani, meg kell javitani, mert nem kétséges, hogy a nemzet értelmi, erkölcsi stb. szempontból csak igy tökéletesedhet”. A tanácsjegyző úr azt a nézetet képviselte - a Polgári Jog címú folyóirat hasábjain megjelent számos tanulmánnyal szemben - hogy a közjognak a magánjogba való beavatkozása szükséges és a nemzeti célokat előtérbe kell helyezni az egyéni érdekekkel szemben. Álláspontja szerint, míg az „élettárs kiválasz̨ása az ember személyes szabadságáboz. tartozik”, a házasságkötés előtti „keötelező" orvosi vizsgálat ügye is azért nem tudott Európában kellöképen haladni, mert sokan már a kötelezó orvosi vizsgálatban is a személyes szabadság sérelmét látták. Kétségtelen, hogy a házasságkötéstöl való eltiltás beleütközilk a személyes szabadságba. De beleütközile akekor is, ha a vérrokonokat tiltjuk el az egymással való bázasságkötéstöl. Senkinek sem jut eszébe eźt kifogásolni.” Szerinte „az egyéni szabadság csak addig számithat védelemre és korlátlanságra, amig bele nem ütkö̈rik a nemzet létfontosságú érdekeibe. A nemzetegészségügy elsörendü fontosságával szemben az egyéni szabadság korlátlanságának kell félre állnia. Az elsö a nemzet egészségének védelme és fejlesztése, ami csak úgy valósitható meg, ha az egyéni szabadság korlátozása árán is eltiltjuk a házasságkötéstöl azt, aki a család, a nemzet egészségét veszélyezteti." Szentmiklósi szerint tovább kell menni és a vizsgálatot végző orvos által kiállított egészségi-bizonyítvány bemutatását - amely bizonyítja, hogy a házasuló fél nem szenved örökölhető, vagy olyan fertőző betegségben, amely a másik házasuló fél vagy a házasságból származó utód egészségét veszélyezteti - a házasságkötés előfeltételévé kell tenni. Úgy gondolta, hogy „gondoskodni kell alkotmánybiztositékeként arról is, hogy ha azorvos a bizonyitvány kiállitását megtagadná és a ąt a fél magára nézve sérelmesnek találná, panasszal fordulhasson a királyi törvényszéekhez, aki a panasz felett peren kivüli eljárásban orvosszakértök. meghallgatása után határozna". 44

\footnotetext{
42 BECK, A jog tragikuma 118-120.

43 VLADÁR, Az élet elhajlása a jogtól 129-144.

${ }^{44}$ SZENTMIKLósI, A házasságkötés előtti 319-321.
} 
A szerző később a Magyar Jogi Szemlében 1942-ben tényszerűen ismertette a „fajvédelmi törvény” rendelkezéseit, szerinte, amire a javaslatból törvény lett, „lényegesen veszített az engenetikai jellegéböl”." 45

\section{6. Összegzés}

Összességében tehát a magyar jogásztársadalom és a Német Jogakadémia kapcsolatáról elmondható, hogy Mikecz és Radocsay igazságügyminiszterek jó kapcsolatot ápoltak a Német Jogakadémiával, annak levelező tagjai is voltak. Amennyiben az elnökük és alapítójuk, Frank Magyarországra látogatott és előadást tartott, azon a vezető tisztséget betöltő jogászok feltehetően protokolláris jelleggel - megjelentek. Ezekről az eseményekről csupán propaganda értékủ tudósításokat lehet fellelni, így azt nem tudhatjuk meg belőlük, hogy a valóságban miként vélekedtek az előadásokról a megjelent jogászok.

Néhány kivételtől eltekintve a korszak magánjogi jellegű jogkorlátozó és jogfosztó rendelkezéseivel szemben éles kritikát nem tapasztalhattunk a tudományos folyóiratokban. A korszak „legnagyobb hangja” Mesұlény volt, akinek 1937-ben bekövetkezett halála megakadályozta, hogy a teljes Horthy-korszak alatt kifejthesse a véleményét a magánjog védelme érdekében.

A magánjogot érintő jogfosztásokkal kapcsolatos nyilvános véleménynyilvánítás hiányának egyik indoka lehet, hogy a korszakot inkább a közjogi, mint a magánjogi tárgyú rendelkezések jellemezték. Ezt fejti ki Ifj. Nagy a Polgári jogban, aki Ceasar csőd- és kamattörvényei, Napóleon Code Civil-je és Moussilini Codice di commercio-ja példáján keresztül igyekezett alátámasztani azt a premisszáját, hogy „a diktatúrák alatt a közjogok (alkotmány, büntetö jog) aránytalanul többet szenvednek, mint a magánjog, melynek sokszor érinthetetlen eszméi elött a leghatalmasabb diktátor liktorai is meghajtják a vesszônyalábokat". 46

A másik indokként az jelölhető meg, hogy a jogbizonytalanság korszakában nyíltan nem helyezkedtek szembe a magánjogászok a hatalommal, félve az esetleges megtorlásoktól. Kevesen emelték fel a hangjukat a magánjog védelmében, erre utalnak Meszlény következő szavai: „Persz̨e, bogy mely idök normálisake és melyek nem azok, ez felfogás és sokban - érzékenység dolga. Vajon ma normálisake? Vagyunk egynébányan, akik arra habozás nélkül nemmel felelünk. A bivatalos felfogás azonban az̧, hogy igen. Fiat applicatio. ${ }^{\text {,4 }}$

\section{Felhasznált források és irodalom}

A birodalmi igazságügyminiszter pályafutása és munkássága a német jog újjáalakításában. Budapest Hírlap, 1938. október 20.7.

A debreceni egyetem jogi fakultásán zsidó hallgatók megzavarták az előadásokat. Debreczeni Ujság, 1932. november 17. 3 .

ALFÖLDI Ede: A törvényhozó hatalom korlátai. Polgári Jog 1927/4-5. 85-87.

ALMÁsI Antal: A magyar magánjog jellemzése. Jogtudományi Közlöny 1921/21. 163-164.

ALMÁsI Antal: A polgári törvénykönyv. Polgári jog 1925/1. 8-13.

\footnotetext{
45 SZENTMIKLósI, Házassági jogunk reformja 15-23.

${ }^{46}$ IfJ. NAGY, Politikai diktatúra és magánjog 289-292.

${ }^{47}$ MESZLÉNY, Nyári tépelődések 105-106.
} 
Az eltartásra jogosult családtagok és a házasságon kívül született gyermekek fokozottabb magánjogi védelméről szóló 3982/1916. M. E. számú rendelet

BECK Salamon: A jog tragikuma. Polgári Jog 1934/3. 118-120.

Dr. Hans Frank német birodalmi miniszter budapesti előadása. Magyar Jogi Szemle 1938/9. 416-418.

Frank birodalmi miniszter Budapestre utazása előtt nyilatkozik a Budapesti Hírlapnak. Budapest Hírlap, 1938. október 20. 7.

Frank Hans német birodalmi miniszter előadása a magyar jogászok előtt. Nemzeti Ujság, 1938. október 22. 6.

Magyarország felismerte az új Európában reá váró feladatokat és törvényesen megteremti a szükséges feltételeket. Ünnepélyesen fogadták Berlinben a magyar igazságügyminisztert. Függetlenség, 1941. szeptember 10. 3.

Németországi utam eredménye a legvérmesebb eredményeimet is felülmúlta - mondotta a Németországból hazaérkező Radocsay igazságügyminiszter. Függetlenség, 1941. szeptember 18. 3.

HERGER Csabáné: Az igazságosság és a jogtalanság határai a magyar magánjogban (1920-1944). Jura 2019/1. 94-103.

Hogyan került egy kóbor kutya Marton Géza professzor tantermébe? Magyar Hírlap, 1932. november 22. 3.

HUNGARUS: A zsidók közéleti és gazdasági térfoglalásáról szóló törvényjavaslat elvi alapja. Magyar közigazgatás 1939/6. 2-3.

IfJ. NAgy Dezső: Politikai diktatúra és magánjog. Polgári Jog 1925/7. 289-292.

IfJ. NAGY Dezső: Törvény vagy rendelet? Polgári Jog 1934/1. 11-13.

Jogi alapokon nyugvó békékre. Nemzeti Ujság, 1938. október 22. 6.

LUGOSI András: „Sztálin föhercege” - Kohn báró vacsorái a Falk Miksa utcában a fajgyalázási törvény idején. Fons 2010/4. 527-576.

Magyar Távirati Iroda, 24. kiadás, 1938. június 18. 17 óra 20 perc. Mikecz igazságügyminiszter előadása nevű dokumentum

Magyar Távirati Iroda, 26. kiadás, 1938. június 18. 18 óra 5 perc. Mikecz igazságügyminiszter előadása, II. folytatás nevü dokumentum

MESZLÉNY Artur: A jog eldurvulása. Jogtudományi Közlöny 1922/7. 69-70.

MESZLÉNY Artur: Az igazságügy reformjához - Nyílt levél Dr. Schiffer Eugen ny. németbirodalmi igazságügyminiszter és helyettes kancellár úrhoz. Polgári Jog 1929/1. 1-7.

MESZLÉNY Artur: Beköszöntő. Polgári jog 1925/1. 1-4.

MESZLÉNY Artur: Földbirtokreform és magánjog. Jogtudományi Közlöny 1922/21. 162-163.; 1922/22. 7.; $1922 / 24$. 190-191.

MESZLÉNY Artur: Jogpolitika. Polgári jog 1925/5. 193-196.

MESZLÉNY Artur: Morál és jog. Jogtudományi Közlöny 1923/6. 41.

MESZLÉNY Artur: Nyári tépelődések. Jogtudományi Közlöny 1922/14. 105-106.

MESZLÉNY Artur: Uj jogszabálytan. Polgári jog, 1925/8-9. 334-341.

MESZLÉNY Artur: Újabb törvényhozásunk és a magánjog. Jogtudományi Közlöny 1922/5. 34.

Mikecz Ödön igazságügyminiszter a Német Jogakadémia levelező tagja. Budapesti Hírlap, 1938. június 19. 12.

Mikecz Ödön igazságügyminiszter előadást tartott Berlinben a magyar alkotmányjogunk és büntetőjogunk fejlődéséről. Pécsi Napló, 1938. június 19. 4.

Mikecz Ödön nagysikerű előadása Berlinben a magyar alkotmány és jogalkotás fejlődésérôl. Uj Magyarság, 1938. június 19. 7.

Radocsay hétfőn este visszautazott Németországból Budapestre. Nemzeti Ujság, 1941. szeptember 16. 7.

Radocsay igazságügyminiszter Berlinbe utazott - Meglátogatja a német bíróságokat és igazságügyi intézményket. Függetlenség, 1941. szeptember 7.2.

Szemle. Jogtudományi Közlöny 1921/20. 158-159.

SZENTMIKLÓSI István: A házasságkötés előtti kötelező orvosi vizsgálat kérdéséhez. Polgári Jog, 1938/6. 319-321.

SZENTMIKLÓSI István: Házassági jogunk reformja. Magyar Jogi Szemle 1942/1. 15-23.

UDVARos Miklós: A háborús bűnök nem évülnek el. Jogtudományi Közlöny 1979/12. 683.

VÉRTESI Dezső: Frank dr. nyilatkozata budapesti útjáról. Budapest Hírlap, 1938. október 20. 7.

VlaDÁr Gábor: Az élet elhajlása a jogtól. Polgári Jog 1938/3. 129-144. 